\title{
COPYRIGHT PROTECTION OF ARCHITECTURAL PLANS, DRAWINGS, AND DESIGNS
}

\begin{abstract}
Arthur S. Katz*
"The final cause of law is the welfare of society. The rule that misses its aim cannot permanently justify its existence . . . Logic and history and custom have their place. We will shape the law to conform to them when we may; but only within bounds. The end which the law serves will dominate them all."

Cardozo, The Nature of the Judicial Process 66 (I92i).

"Perhaps the most significant advance in the modern science of law is the change from the analytical to the functional attitude."

Dean Pound, quoted in Cardozo, The Nature of the Judicial Process 73 (1921).

How much protection is available to the creator of architectural plans, drawings, and designs under copyright principles? Is this protection similar in scope to that granted such producers of intellectual property as authors, artists, and composers? It is the purpose of this article to answer these questions.
\end{abstract}

\section{The Concept of Copyright}

An appreciation of the scope of protection available to the architect under copyright principles can best be accomplished by first examining the nature of copyright. Drone, the dean of American text writers on matters of intellectual property, has defined copyright as follows: ${ }^{1}$

Copyright is the exclusive right of the owner to multiply and to dispose of copies of an intellectual production. It is the sole right to the copy or to copy it. The word is used indifferently to signify the statutory and the common-law right of the owner in a literary or musical composition or work of art. As there are essential differences between the two rights, one is sometimes called copyright after publication, or statutory copyright; and the other copyright before publication, or common-law copyright. Copyright is also used synonymously with literary property ... This is not strictly correct. ...

The right granted is quite limited. For example, an author of a book is given the exclusive right to exploit his work by making copies of it. The law prevents others from copying his work since he has the sole copy-right. However, as will be demonstrated, the author's copyright does not bar others from using the ideas or thoughts contained in his work. It is solely the expression or arrangement which is protected from copying. ${ }^{2}$

* A.B. 1948, Brooklyn College; LL.B. I950, New York University School of Law. Member of the New York and California bars. Department Head, Copyright \& Television Department, Columbia Pictures Corporation, Hollywood, Calif. Counsel to architectural firms. West coast editor, Bulletin of the Copyright Society of the United States of America. Member, Los Angeles Copyright Society. Author of various articles on copyright law and constitutional law.

2 Eaton S. Drone, a Treatise on the Law of Property in Intellectual Productions in Great Brutain aNd the UNited States ioo-Iol (1879) [cited hereinafter as Drone on Copyright].

${ }^{2}$ For a discussion of these principles, see pages $239-24 \mathrm{I}$, infra, and notes and cases there cited. 
The term "copyright" is a misnomer. There are many intellectual productions which are imperfectly exploited, from the pecuniary point-and as works of art, when rendered solely as printed copies. For instance, musical and dramatic works are primarily intended to be performed. A painter's or sculptor's design for a work of art is intended to be executed or completed. Dollar-wise or culturally, the nonexecuted design would have little value. Consequently, the law recognizes the existence of "play-rights," "performance rights," and "execution rights" in appropriate intellectual productions. ${ }^{3}$ And it protects these rights. Notoriously no respecter of persons, the law is also rude with semantics. Under the cloak of copyright, it shields play-rights, performance rights, and execution rights as well. ${ }^{4}$

Broad though it is, the Anglo-American concept of copyright should also be seen in its proper perspective. The law of copyright must be recognized as filling but a limited area in the field of intellectual property. Under Anglo-American law, an author can rarely, in the absence of contract, protest the misuse or mutilation of his copyrighted work. 5 The protection granted a creator under copyright principles is limited to pecuniary matters. Protection of a creator's non-patrimonial interest in his work, that is, protection against an invasion of his right of personality by an indiscriminate use of his work, is not found in Anglo-American copyright law. However, these non-patrimonial interests are adequately safeguarded in most countries by exercise of the moral right doctrine, le droit moral. ${ }^{6}$ Further, certain unethical commercial abuses of intellectual productions are not cognizable under copyright principles. ${ }^{7}$

To restrict the creator of an intellectual production solely to the limited protection afforded by the law of copyright is to leave him ill armed to combat the host of parasites who would feed gratuitously on his creation.

Although the body of copyright law is too small to cover the intellectual property field, it has, nevertheless, expanded in other ways: It has grown two separate heads. One head is labeled common-law copyright; the other, statutory copyright. As Drone has stated: ${ }^{8}$

... there are important differences between the statutory and common-law right. The former exists only in works which have been published within the meaning of the statute; and the latter, only in works which have not been so published. In the former case, ownership is limited to a term of years; in the latter, it is perpetual. The two rights do not coexist in the same composition; when the statutory right begins, the common-law

${ }^{3}$ For a discussion of these rights, see pages 239,247 , infra, and notes and cases there cited.

'To say nothing of a host of other rights, such as those of translation, dramatization, adaptation, etc. See I7 U. S. C. \$I (Supp. 1952).

${ }^{-}$Compare Curwood v. Affiliated Distributors, Inc., 283 Fed. 219 (S. D. N. Y. 1922) and Drummond v. Altemus, 60 Fed. 338 (C. C. E. D. Pa. 1894) with Clemens v. Belford, Clark \& Co., I4 Fed. 728 (C. C. N. D. Ill. 1883 ).

'See Katz, The Doctrine of Moral Right and American Copyright Law-A Proposal, 24 So. Caurf. L. REv. 375 (I951), Fourth Copyright Law Symposiun 78 (ASCAP I952); Roeder, The Doctrine of Moral Right: $A$ Study in the Law of Artists, Authors, and Creators, 53 Harv. L. Rev. 554 (I940); Granz v. Harris, 198 F. 2d $585,590,59 \mathrm{r}$ (2d Cir. 1952).

'See page 249 , note 153 and cases and authorities cited in the Appendix, infra.

${ }^{8}$ Drone on Copyright ioo. 
right ends. Both may be defeated by publication. Thus, when a work is published in print, the owner's common-law rights are lost; and, unless the publication be in accordance with the requirements of the statute, the statutory right is not secured.

An examination of Anglo-American legal history explains this duality of copyright. The first English copyright statute (8 Anne, c. 19) was passed in I709. It was designed to aid authors of published works by giving them the right to have penal sanctions applied to infringers. The Court of King's Bench interpreted this statute in $I 769$ in Millar $v$. Taylor..$^{9}$ It held that the act was declaratory of the common law, that it was a penal statute which gave an additional remedy to an author in his fight against literary piracy, and that it was not intended to divest the author of his perpetual common law right in his property, whether published or unpublished. ${ }^{10}$

In I774 the statute was again subjected to scrutiny. The case of Donaldson $v$. Becket ${ }^{11}$ came before the House of Lords upon an appeal from a decree by the Lord Chancellor which had made perpetual the injunction granted in Millar $v$. Taylor. It was the defendant's argument that "The Statute of Anne was not declaratory of the common law, but introductive of a new law, to give learned men a property they had not before."12 By a count of six to five, the eleven judges hearing the argument of the case voted to reverse Millar $v$. Taylor. They held that the statute did take away an author's common law right in his published work. ${ }^{13}$

The law in the United States is in accord with Donaldson v. Becket. The statute of 8 Anne, c. Ig, not being a part of the common law, was never applicable to the United States. Nevertheless, the United States Supreme Court in Wheaton $v$. Peters $^{14}$ cited the above decision as its authority for holding that the first federal copyright law, the Copyright Act of $1790{ }^{15}$ destroyed common law rights in published works. Thus, in both the United States and the United Kingdom, copyright in published works was early deemed to be a creature of statute.

Since the passage of the Copyright Act of $\mathrm{IgIx}^{16}$ there has been no common law copyright in the United Kingdom, all intellectual productions, published or unpublished, being protected only by statutory fiat. In this country, contrarily, the difference between common law and statutory copyright remains.

${ }^{\circ} 4$ Burr. 2303, 98 Eng. Rep. 201 (K. B. 1769).

${ }^{10}$ For a detailed examination of this decision see DRONE ON Copyrigur 28 et seq.; see also Katz, supra note 6 , at $382-384$.

114 Burr. 2408, 98 Eng. Rep. 257, 2 Bro. P. C. 129, r Eng. Rep. 837 (1774).

- ${ }^{12}$ Donaldson v. Becket is reported in at least two versions. The portion quoted appears in 2 Bro. P. C. 129 , at I 40 .

${ }^{13}$ For a detailed examination of this decision see Drone oN Copyright 37 et seq.; see also Katz, supra note 6 , at $384-385$.

148 Pet. 59 I (U. S. $x 834$ ).

${ }^{25}$ Prior to the passage of this act by the Second Session of the First Congress on May 31,1790, I STAT. 124, twelve of the original thirteen states (Delaware being the exception) had passed copyright laws. With the adoption of the Federal Constitution these states statutes were, of course, superseded by federal legislation. For the text of these statutes see Copyright Laws of the United States of America I-24 (Copyright Office r952).

I0 I \& 2 GEo. 5, c. $46, \$ \$ I, 3 I$. 
Statutory copyright is a federal right created by authority of the United States Constitution. ${ }^{17}$ Thè current copyright law ${ }^{18}$ has preserved a creator's rights, under common law and equitable principles, in his unpublished work. ${ }^{10}$ Since there is no federal common $1 \mathrm{aw},{ }^{20}$ the state courts are the appropriate forums in which to resolve common law copyright questions. ${ }^{21}$ Although one might wish that certain state courts displayed a keener understanding of the concept of copyright, there appears to be little basis to the assertion that common law copyright ${ }^{22}$ is either nonexistent in most states or erratically adjudicated from state to state. Common law copyright questions have not been raised in every state; nevertheless, no decision or piece of legislation has been reported where a state or territory in the Union has denied the existence of common law copyright. ${ }^{23}$

We have noted, thus far, the following basic differences which distinguish common law copyright from statutory copyright: ${ }^{24}$

(a) Common law copyright exists solely in unpublished works; statutory copyright (with certain specific exceptions) exists only in published works.

(b) Common law copyright protection is automatically accorded all unpublished works

17 "The Congress shall have power ... to promote the Progress of Science and useful Arts, by securing for limited Times to Authors and Inventors the exclusive Right to their respective Writings and Discoveries." U. S. ConsT., Art. I, $\$ 8$.

${ }^{18}$ Act of March 4, I909, 35 SrAT. 1075 (r909) [which act, as amended, is codified as r7 U. S. C. (Supp. 1952)].

${ }^{10}$ I7 U. S. C. \$2 (Supp, I952):

"Rights of Author or Proprietor of Unpublished Work.-Nothing in this title shall be construed to annul or limit the right of the author or proprietor of an unpublished work, at common law or in equity, to prevent the copying, publication, or use of such unpublished work without his consent, and to obtain damages therefor."

${ }^{20}$ Erie R. R. v. Tompkins, 304 U. S. 64 (1938).

${ }^{21}$ However, if the amount in controversy exceeds $\$ 3,000$ exclusive of interest and costs, and there is diversity of citizenship, suit may also be brought in a federal court.

Conversely, where litigation concerns a breach of contract or the abuse of a relationship connected with a statutory copyrighted work, the state courts have jurisdiction. Condon v. Associated Hospital Service, 287 N. Y. 4 II, 4r4, 40 N. E. $2 \mathrm{~d} 230$ (1942).

22 The writer uses the terms "common law" and "common law copyright" to signify that broad, unwritten and judge-made body of English law based on usage and timeless custom which is distinguished from legislative enactments. With the exception of portions held repugnant to American religious, social or political mores, this body of law has been carried over into American state and federal jurisprudence. See Western Union Telegraph Co. v. Call Pub. Co., I8I U. S. 92 (Ig0r). The writer does not use these terms to represent the unwritten and judge-made law of the United States.

${ }^{28}$ According to a report prepared by Leonard Zissu, Esq., for presentation at the I953 American Bar Association meeting in Boston, Mass. ". . . no statutes or judicial decisions of any states or territories of the U. S. A. have yet been produced to support the contention that common law protection in unpublished works or its equivalent in noncommon law states or territories does not presently exist. Indeed, the statutes and judicial decisions which do exist uniformly indicate a general policy among the states and territories to furnish such protection .... no state or territory has legislatively denied or abrogated such protection and only six jurisdictions have no legislation thereon whatsoever (Arizona, Arkansas, Colorado, Delaware, Missouri, Tennessee and Puerto Rico)." [Mr. Zissu was quoting from a report by Wilma Stine.]

The courts of New York State, for instance, follow common law copyright precepts, although there is no statutory declaration of them. Oertel v. Wood, 40 How. Prac. xo (N. Y. 1877); Chamberlain v. Feldman, 300 N. Y. 135,89 N. E. 2 d 863 (I949).

The State of California, on the other hand, has codified the concept of common law copyright. See Car. Crv. Code $\$ \$ 980$, et seq.

${ }^{24}$ See however, note 22, supra. 
from the moment of their creation. The mere act of publication will not automatically grant statutory protection to a work; there must be, in addition, strict compliance with the statutory formalities.

(c) Common law copyright protection is perpetual; statutory copyright is for a term of years.

(d) Common law copyright is regulated by the several states; statutory copyright is solely a matter for the Federal Government.

There are two other basic differences between the two branches of copyright. These are differences which appreciably affect the practical question of determining how and when an intellectual production is infringed.

Common law copyright is a negative sort of protection. It grants nothing to the creator of intellectual property which he did not previously possess. Instead, it aids him in preserving inviolate his unpublished work. In essence, the common law protects his right of secrecy, his right to control the first publication of his work. $^{25}$ After an authorized publication, common law protection ceases. ${ }^{20}$

Statutory copyright may be described as granting positive protection. Under its principles, intellectual productions may be exploited free from the threat of misappropriation. The courts have agreed that statutory copyright has given the creator of published intellectual works a new property right. ${ }^{27}$ In consideration of the receipt and enjoyment of this grant of new protection, the state has required that the creator give something in return. The quid pro quo is the right given to others to make a "fair use" of the material protected by statutory copyright. ${ }^{28}$ Knowl-

${ }^{25}$ As superbly stated by Lord Mansfield in Millar v. Taylor, 4 Burr 2303, 2398, 98 Eng. Rep. 201, 252 (K. B. 1769 ):

"From what source, then, is the common law drawn, which is admitted to be so clear, in respect of the copy before publication?

"From this argument-because it is just, that an author should reap the pecuniary profits of his own ingenuity and labour. It is just, that another should not use his name, without his consent. It is fit he should judge when to publish, or whether he will ever publish. It is fit he should not only choose the time, but the manner of publication; how many; what volume; what print. It is fit, he should choose to whose care he will trust the accuracy and correctness of the impression; in whose honesty he will confide, not to foist in additions: with other reasonings of the same effect.

"... But the same reasons hold, after the author has published. He can reap no pecuniary profit, if, the next moment after the work comes out, it may be pirated upon worse paper and in worse print, and in a cheaper volume.

“. . . The author may not only be deprived of any profit, but lose the expence he has been at. He is no more master of the use of his own name. He has no control over the correctness of his own work. He cannot prevent additions. He cannot retract errors. He cannot amend; or cancel a faulty edition. Any one may print, pirate and perpetsate the imperfections, to the disgrace and against the will of the author; may propagate sentiments under his name, which he disapproves, repents and is ashamed of. He can excrcise no discretion as to the manner in which, or the persons by whom his work shall be published." (Italics supplied.)

20 "The owner's common-law rights are not lost by a publication which is made without his authority. In that case, the act is not his, and he cannot rightly be held responsible for what is done without his knowledge or consent. But long acquiescence may amount to abandonment." Drone oN COPYRIGHT I2X.

${ }^{27}$ Donaldson v. Becket, 4 Burr. 2408, 98 Eng. Rep. 257, 2 Bro. P. C. 129, I Eng. Rep. 837 (1774); Wheaton v. Peters, 8 Pet. 59 r (U. S. r834).

28 "The aim of the law is to encourage learning by allowing a fair use to be made of a copyrighted 
edge, obviously, is most valuable when shared. Of course, abuse of this "conditional privilege" to draw material from the storehouse of another will constitute an "unfair use," a "misappropriation of intellectual property," and hence, an infringement. One of the most difficult questions in statutory copyright is to determine when a taking is "fair" and permissible, or "unfair" and an infringement. The legal test is simple: where the matter taken is a substantial or material part of the protected work, there is an infringement. Its application is difficult. This test will be discussed in detail in a later portion of this article. ${ }^{2 \theta}$

In as much as common law copyright is not a new right given by the state, there is no requirement for a quid pro quo. Accordingly, the doctrine of "fair use" is not found in common law copyright. The law has been clearly stated by the Supreme Court of California: ${ }^{\mathbf{3 0}}$

... common-law rights in unpublished works are of a wider and more exclusive nature than the rights conferred by statutory copyright in published works (court's italics). The common law prohibits any kind of unauthorized interference with, or use of, an unpublished work on the ground of an exclusive property right... A statutory copyright permits a "fair use" of the copyright publication without deeming it an infringement. (Italics supplied.)

Whether the right to protest any unauthorized use of an unpublished work is a property right, ${ }^{31}$ or a right of personality, ${ }^{32}$ the fact remains that the improper taking of only a scintilla of unpublished material is a wrong for which the law gives a remedy. It is questioned whether the doctrine of de minimis non curat lex is here applicable since the wrong is not so much the taking of property as it is the violation of the author's right of secrecy.

With this discussion of the basic differences between common law and statutory copyright we have concluded our analysis of the concept of copyright. We shall now proceed to examine the nature and scope of the protection available under common law copyright to architectural plans, drawings, and designs.

\section{Common Law Copyright}

The architect ${ }^{33}$ expresses his thoughts and reveals his artistic personality in his "writings."34 In this respect, he is similar to all other creators of intellectual prop-

work, but at the same time to prevent the subsequent author from saving himself labor by appropriating without consideration the fruits of another's skill and industry." Drone on Copyright 398. .See also Drone at 386, 387. Lawrence v. Dana, 15 Fed. Cas. No. 8,136 at 26, 60-6r (C. C. D. Mass. I869).

${ }^{20}$ See pages 242,243 , infra, and cases and notes there cited.

${ }^{30}$ Stanley v. Columbia Broadcasting System, 35 Cal. 2d 653, 66r, 22I P. 2d 73, 78 (1950).

31 Gee v. Pritchard, 2 Swanston 402, 36 Eng. Rep. 670 (Ch. 1818); Baker v. Libbie, 210 Mass. 599, 97 N. E. Io9 (1912).

${ }^{32}$ See Katz, supra note 6 , at $375,390,399-402$.

${ }^{33}$ Wherever the term "architect" appears in this article it should be recognized as referring to "designers" as well.

si The courts have long given a liberal interpretation to the term "writings" as contained in the constitutional provision authorizing copyright protection. For the pertinent text of this provision see note I7, supra. The leading decision on the point is Burrow-Giles Lithographic Co. v. Sarony, xir U. S. $53(1884)$. See also Title I7 U. S. C. $\$ 4$ which declares that works which are copyrightable under the act "include all the writings of an author." 
erties. Unlike the writer of books, the architect is not limited to words. In addition to words, he uses, among other things, technical signs and symbols and graphic representations to communicate his ideas. The architect might be compared to the composer of music. The architect's signs, symbols, and graphic representations are to the builder what a composer's notes and performance instructions are to the musician.

The writer has chosen to group all of the architects's writings under the collective caption of "plans, drawings, and designs." Architects, generally, use the word "drawings" to cover all written expressions of their art. However, the word has acquired too narrow an interpretation in the average person's vocabulary to warrant its use as a complete description of an architect's writings. Nor is the term "design" an apt means of describing all of an architect's writings. Like a carefully phrased campaign promise, it means different things to different people. For the purposes of this article, a design is not only a two dimensional drawing or sketch of an architectural work in the round, or a three dimensional model of such work. It is also any eye-pleasing drawing, detail, pattern, form, or arrangement of materials which is primarily intended to have an artistic or ornamental effect. The artistic use of wood strips, or "trim" on the exterior of a house to enhance its charm is an example of the latter use of the term "design." 35

In addition to drawings and designs, an architect uses the "plan," a two dimensional medium, to express his ideas for the erection of three dimensional structures. For structures such as houses, the most basic plan is the "floor or ground plan." This is a graphic or schematic drawing which delineates the form, size, room arrangement, and construction features of one floor of a structure as if seen from overhead, ceiling or roof removed. The floor plan gives a horizontal structural description. To describe vertical planes, such as walls, windows, doors or façades, "elevations" are employed. These may be "framing elevations" which reveal the construction details, or "skeleton" of a structure, or they may represent the completed vertical planes with their "skin" on. And, of course, there are interior and exterior elevations.

The modes of expression or writing available to the architect are many. Yet the law is clear that his unpublished work, be it denominated plan, drawing or design, is protected under common law copyright principles from any unauthorized

${ }^{35}$ Designs, in the latter sense, may be protectible under either the copyright or patent laws, or under both. Copyright protection is not dependent upon the intended use of the object upon which the copyrighted design is placed. Rosenthal v. Stein, 98 U. S. P. Q. 180, 205 F.2d 633 (9th Cir. 1953). Contra: Stein v. Expert Lamp Co., 96 F. Supp. 97 (N. D. Ill. x951), aff'd 188 F. $2 d$ 6xi (7th Cir. 195I), cert. denied, 342 U. S. 829 (195I). See 17 U. S. C. \$5(g) (Supp. 1952); see also Regulations of the Copyright Office in 37 CODE of Federal Regulations c. II, \$202.8 (1948). Sec also 35 U. S. C. \$I7I (Supp. 1952).

For the difference between design patents and patents for other inventions, see the "Kewpic doll" case, Wilson v. Haber Bros., Inc., 275 Fed. 346, 347 (2d Cir. 192x). 
use. $^{38}$ The wrong-doer will be enjoined ${ }^{37}$ and, in some cases, held liable for damages. 38

Of course, the work must be original ${ }^{30}$ as well as unpublished, that is, it must be the result of independent labor and not of copying. ${ }^{40}$ However, the work need not be the first of its kind. ${ }^{41}$ Although the concept of "newness" or novelty is a prerequisite in the law of patents, ${ }^{42}$ it has no place in the fields of common law ${ }^{43}$ or statutory copyright. ${ }^{44}$

Novelty is a concept incapable of clear-cut definition. Novelty does have some measurable basis where its scope is limited in territory and time. ${ }^{45}$ To require an author, who has created something original, to warrant and prove that it is also novel, that it has never been done before anywhere at any time, is to confront him with an obstacle too difficult to overcome. History has recorded numerous incidents where two gifted men, working unaware of the other's efforts, have arrived, almost simultaneously, at the same results or discoveries. Yet if absolute novelty must be proven before either could restrain the unauthorized publication of his work, neither would receive protection. It should be sufficient that the work of each author is new to him, that is, that it is original with him, and not copied from the work of another. ${ }^{46}$

${ }^{30}$ Drone on Coprrighr, I01, 102. See also page 229 and note 30, supra.

${ }^{3 r}$ See cases cited in gote 31 supra.

${ }^{38}$ Jefferys v. Boosey, 4 H. L. Cas. 8I5, 962, Io Eng. Rep. 68I (I854); Caliga v. Inter Ocean Newspaper, 215 U. S. 182 (1909). For a discussion of the measure of damages see Taft v. Smith, Gray \& Co., I34 N. Y. Supp. IoII (App. Term. Sup. Ct. I912).

so ". . . originality is alone the test of validity [of a copyright]," Learned Hand, J., in Fisher v. Dillingham, 298 Fed. 145, I49-152 (S. D. N. Y. 1924); Drone on Copyright, I98, 199. See Yankwich, Originality in the Law of Intellectual Property, xI F. R. D. 457 (195I).

See also pages $240-242$ infra, and cases and notes there cited.

${ }^{10}$ Drone on Copyright, 208.

41 "No one doubts that two directories, independently made, are each entitled to copyright, regardless of their similarity, even though it amount to identity. Each being the result of original work, the second will be protected, quite regardless of its lack of novelty." Learned Hand, J., in Fisher v. Dillingham, 298 Fed. 145, 150, 15 I (S. D. N. Y. 1924).

${ }^{2}$ See 35 U. S. C. \$\$ror, ro2 (Supp. I952).

${ }^{43}$ Drone on Copyright, I99, 200.

"s "Unlike the subject matter of a patent, copyrighted material need not be new, but only originall" Clark, C. J., in Ricker v. General Electric Co., I62 F. 2d I4I (2d Cir. I947); Chamberlin v. Uris Sales Corp., 150 F. 2d 512 (2d Cir. 1945); Fisher v. Dillingham, 298 Fed. I45 (S. D. N. Y. I924).

For a further discussion of the concept of novelty in works protected by statutory copyright see page 240 infra, and cases and notes there cited.

${ }^{45}$ See 35 U. S. C. \$102 (1952) where an invention is deemed to be new, and within the purview of the United States Patent Law, if, among other things, the invention ( $I$ ) has not been known or used by others in this country, or patented or described in a printed publication in this or any country prior to its invention by the applicant, or (2) has not been patented or described in a printed publication in this or any country for more than one year prior to the invention's United States patent application.

${ }^{\circ}$ Melville B. Nimmer, Esq., in his ground breaking article, The Law of Ideas, 27 So. Calif. L. Rev. IIg (I954), points up the confusion engendered by many courts by their misuse of the terms originality and novelty.

Confusion must result as to the true nature of copyright where the courts interject the element of novelty as an aid to establishing the originality of a work in those cases where both the plaintiff's and defendant's properties use similar stock incidents and characters. It is submitted that when courts speak of the requirement of "a new conception or novel arrangement" they mean only that an author's work must be sufficiently different in expression or development as to indicate that it is original 
An original unpublished "naked idea" is not protectible at common law. ${ }^{47}$ The undeveloped idea that a house should be built in a circular form to permit all the rooms to receive sunshine at some time in the day is an example. At this stage, the idea is nothing but a thought-ephemeral, intangible, impermanent. To be protected at common law, the unpublished original work must be expressed in a concrete or tangible manner. This does not mean that the author's thought must be set forth in some kind of writing, and that each premise must be completely developed. The requirement of concreteness for intellectual productions would appear to be satisfied where the creator's thoughts are contained in such non-abstract form as would permit the impress of his mark of ownership. ${ }^{48}$

Should the unpublished work be "not capable of distinguishable proprietary marks" ${ }^{\prime 49}$ because of its vagueness of expression, it would be proper to deem it nonconcrete. It would be non-protectible because non-possessible, and non-possessible because it lacked indicia certa. As an able English jurist has stated: ${ }^{60}$

The subject of property is the order of words in the author's composition; not the words themselves, they being analogous to the elements of matter, which are not appropriated unless combined, nor the ideas expressed by those words, they existing in the mind alone, which is not capable of appropriation.

As indicated, the architect employs a specialized form of writing. He expresses himself, primarily, by the use of technical signs, symbols, and graphic representations. Substitute these terms for the term "words" in the above quotation, and one will note its applicability to an architect's intellectual productions.

Protecting the unpublished works of an architect would be a relatively simple matter were the law clear as to what acts constituted publication. Counsel could advise, "do this-avoid doing that," and all would be well-the common law copyright would be preserved against any unauthorized reproduction. But, alas, the law is not clear. The theory of publication is simple enough, but its correct application to a particular set of facts is another matter.

The writer has been able to find but three reported cases in the United States

and not copied from the protected work of another or from public domain material to which the plaintiff had access. A case in point is: Simonton v. Gordon, 297 Fed. 625 (S. D. N. Y. 1924).

"It follows that the less developed the characters, the less they can be copyrighted; that is the penalty an author must bear for marking them too indistinctly" (italics supplied), Learned Hand, C. J., in Nichols v. Universal Pictures Corp., 45 F. $2 \mathrm{~d}$ 119, I2I (2d Cir. 1930).

"However, an unpublished "naked idea" which has been revealed through a breach of trust or confidence is protectible under common law principles. Here the protection is not the affirmative kind afforded property. It is negative in nature; the wrong-doer is prevented from profiting from his tortious acts. For a discussion of this point see page 228 supra and cases and authorities cited in the Appendix at pages 251-252, infra. See also Copinger and Skone James on the Law of Copyricht 38, 39 (8th ed. 1948) [this authoritative English text is cited hereinafter as Copinger on Copyrighr].

¿8 "The best rule both of reason and justice seems to be, to assign to cverything capable of ownership a legal and determinate owner." (Italics supplied.) MAugham, A Treatise on the LAws of Litrnary Property 4 (1828). See also the fine survey of Anglo-American decisions in Pannone, Property Rights in an Idea and the Requirement of Concreteness, 33 Boston U. L. REv. 396 (1953).

${ }^{49}$ Millar v. Taylor, 4 Burr. $2303,2365,2366$, 98 Eng. Rep. 201 (K. B. 1769). But a work is protectible if it does have "a capacity to be distinguished," id. at 2340.

${ }^{50}$ Erle, J., in Jefferys v. Boosey, 4 H. L. Cas. 815,867 , ro Eng. Rep. 681, 702 (1854). 
discussing what constitutes a publication of architectural plans, drawings, and designs. All of them are lower court decisions. A New York Appellate Division case $^{51}$ held that the filing of unpublished plans in a municipal building department which required such filing before construction could be approved, was such a publication of the plans as to destroy the architect's common law rights in them. A Missouri Appellate court ${ }^{52}$ and a Philadelphia City court ${ }^{53}$ have held that the building of a structure from hitherto unpublished plans, and its exposure to public gaze, was also such a publication as destroyed the common law copyright in the plans.

It is submitted that these cases are wrong in principle and destructive in practice of an architect's intellectual property. Should these three lower court cases be deemed to represent the true state of the law, an architect may never properly exploit his unpublished intellectual productions. The two acts which the nature of an architect's calling require him to perform, in order to earn his living, are turned, by these three decisions, into the very means of depriving him of the right to profit from his own labor at the exact moment such profit is realizable. ${ }^{\mathbf{5 4}}$.

From the business point of view, these decisions are unjust. And, as concerns the law, they are unsound. This contention is supported by an examination of the authorities on the concept of "publication."

"Publication," as a legal term, is possessed of many definitions. It means one thing in the law of wills, another thing in the law of defamation, and yet another in the law of copyright. The act of publication communicates the contents of a work to others, generally by the circulation of copies. However, the copyright law distinguishes between communications which divest one of his common law rights in his work, and communications which do not. The former act is deemed a general publication, the latter, a limited publication. "The use of the word 'publication' in these two senses is unfortunate, and has led to much confusion."55

By definition, a general publication is: ${ }^{56}$

... such a disclosure, communication, circulation, exhibition, or distribution of the subject

${ }^{\mathrm{t}}$ Wright v. Eisle, 86 App. Div. 356,83 N. Y. Supp. $88_{7}$ (2d Dep't r903). For the writer's views as to the wisdom of this decision see note 54 and page 235 , infra.

${ }^{2}$ Kurfiss v. Cowherd, 233 Mo. App. 397, 12I S. W. $2 \mathrm{~d} 282$ (1938). See note 53, infra.

${ }^{83}$ Gendell v. Orr, I3 Phila. I9r (1879). The writer did not find the reasoning of this case or of Kurfiss v. Cowherd, supra note 52, persuasive on the point that erection of a building is a publication of its technical writings. See page 236 infra, and notes thereto.

od If the filing of plans, drawings, and designs in governmental offices, or the erection of the structure they describe is held to throw these technical writings into the public domain, the architect is literally forced to divest himself of his exclusive property, contrary to his own desires. He cannot build unless he files; the moment he files he loses his common law rights. His writing then being free for the taking, he can rarely sell more than one copy of these writings, nor receive more than one royalty for their use. Sce also page 235 infra.

Es Townsend, J., in Werckmeister v. American Lithographic Co., I34 Fed. 321, 324 (2d Cir. 1904). To the same end, Hough, C. J., in Associated Press v. International News Service, 245 Fed. 244, 250, 251 (2d Cir. 1917).

00 Townsend, J., in Werckmeister v. American Lithographic Co., 134 Fed. 32I, 326 (2d Cir. Ig04). See National Institute v. Nutt, 28 F. $2 \mathrm{~d} 132$ (D. Conn. 1928), aff'd, 3I F. 2d 236 (2d Cir. 1929). See also cases cited in note 63 infra. 
of copyright, tendered or given to one or more members of the general public, as implies an abandonment of the right of copyright or its dedication to the public.

\section{A limited publication is: 57}

... one which communicates a knowledge of its contents under conditions expressly or impliedly precluding its dedication to the public.

The above definitions are certainly succinct. But, as a matter of practice, how may one type of publication be distinguished from another? The nature of the work concerned has some bearing on the question..$^{58}$ For example, the performance of a dramatic piece or a musical composition is never any kind of a publication thereof. Here the law admits of no doubt. ${ }^{59}$ However, the certainty one seeks in the law becomes less apparent when other intellectual productions are examined. For instance, it is not wholly clear whether the act of exhibition per se of a painting is a publication, and, if so, whether it is general or limited. ${ }^{60}$ In so far as the technical writings of an architect are concerned, they are neither dramatic or musical works, nor intended solely for exhibition purposes. It is evident, therefore, that they are capable of being published, in the fullest legal sense of that term.

But the nature of the intellectual production aside, what other factors determine whether a communication is a publication, and if so, whether it is general or limited? Is the printing of copies a general publication? Does the amount of copies matter? May a work be published generally by the circulation of manuscript copies?

It is submitted that the mechanical means employed to reproduce a work, or the number of copies made and distributed are not determinative of the question of general publication. ${ }^{61}$ The test is one of intention. The Supreme Court of the United States has declared: $:^{62}$

It is a fundamental rule that to constitute publication there must be such a dissemination of the work of art itself among the public as to justify the belief that it took place with the intention of rendering such work common property. [Italics supplied.]

Clearly, an author is not to be lightly divested of his common law protection, and hence of his property, without clear indicia of his intentions. For the law to

${ }^{57}$ Townsend, J., in Werckmeister v. American Lithographic Co., 134 Fed. 321, 324 (2d Cir. 1904). See also Judge Yankwich's scholarly treatment of the point in White v. Kimmell, 94 F. Supp. 502 (S. D. Calif. 1950), rev'd on other grounds, 193 F. 2d 744 (9th Cir. 1952).

${ }^{8}$ Universal Film Mfg. Co. v. Copperman, 212 Fed. 301 (S. D. N. Y. 1914), aff'd, 21 8 Fed. 577 (2d Cir. I914), cert. denied, 235 U. S. 704 (I9I4).

${ }^{69}$ Ferris v. Frohman, 223 U. S. 424 (1912) established this point in American law. The same rule obtains by statute in Great Britain, Copyright Act, x9I1, I \& 2 Geo. 5, c. 46, $\$$ I(3).

${ }^{60}$ See, e.g., WeIl, American Copyright LaW I49-150 (19I7). See also, Drone on Copyright 285-292.

o1 ". . . a work is published when it is communicated to the general public . . . the general unrestricted circulation of printed copies is such a publication, and the principle would seem to be the same when manuscript copies are circulated. But it is clear that a private circulation for a restricted purpose is not a [general] publication ... notwithstanding that the copies so distributed are printed." DroNE oN COPYRIGHT $115,121,290$.

${ }^{02}$ Mr. Justice Day in American Tobacco Co. v. Werckmeister, 207 U. S. 284, 299-300 (1907). 
find a general publication, the facts surrounding the publication must reveal a desire to abandon all rights in the work. A creator of intellectual productions who, by conduct, custom or contract, restricts the use or circulation of his work has made no general publication. ${ }^{63}$ Thus, an architect who discloses his unpublished plans, drawings or designs to a prospective client, or series of clients, does not do so with the intention of abandoning his rights in his work. Such publication as he makes is clearly a limited one.

Does an architect intend to make a general publication when, in conformity with the dictates of a building ordinance, he files his plans in a governmental office? Obviously not. The purpose of the filing requirement is to protect the public from unsafe construction-not to divest the architect of his property. Conversely, if the filing is intended as a condition precedent to the State's action of granting a limited monopoly to the creator, as where a patent right is concerned, the filing is tantamount to a general publication. ${ }^{64}$ This is wholly proper. Since the creator has obtained the exclusive right to exploit his work for a limited time, he is not harmed by having his production exposed to public examination. The filing of architectural plans for building permit purposes should be held, at most, to be a limited publication. The architect files solely with the intention of receiving governmental approval of his plans.

The requirement that plans must be filed and approved before a building permit is issued is a valid exercise of a municipality's police powers. It is submitted, however, that such an ordinance is patently unconstitutional where it is construed as working a general publication of an architect's plans. In effect, such an ordinance takes an architect's property without due process of law. ${ }^{65}$

The problem of determining whether the filing of plans in a governmental office is a general publication is avoided, of course, where the building ordinance clearly indicates a contrary intention. Thus, the Los Angeles City Building Code declares: ${ }^{66}$ "Plans and specifications on file with the Department ... shall not be public records."

We turn now to the question whether the architect intends to make a general

-3 "The law recognizes a vital distinction between the public and the private circulation of copies: The owner may circulate copies of a work among a limited number of persons, with the understanding and on the condition that it is not to be made public. In such case no publication takes place, notwithstanding that the copies so distributed are printed." Drone ON COPYRIGHT 290.

Perhaps the classic illustration of this principle is Thomas Jefferson's 'Notes on Virginia." In answer to a query by a Frenchman, Jefferson wrote an accurate study of his state's history, geography, and economy. Because of the great interest evidenced by European diplomatic circles in his account, he caused 200 copies to be privately printed and distributed to selected readers-all of whom were asked not to publish or otherwise disseminate the work.

The concept of publication should not be so narrowly interpreted as to "limit a lawful business to a few degrees of longitude." Hough, C. J., in Associated Press v. International News Service, 245 Fed. 244, 250 (2d Cir. I917). Accord, Board of Trade v. Tucker, 221 Fed. 305, 307 (2d Cir. r915). [". . . the posting of [trade] quotations ... [to subscribers] on a blackboard ... is not the sort of publication which will terminate complainant's property right in them"] Board of Trade v. McDearmott Commission Co., r43 Fed. I 88 (C. C. W. D. Mo. I906).

“ Korzybski v. Underwood, 36 F. 2d 727, 729 (2d Cir. I929).

${ }^{\circ}$ See note 54 supra. See also Brown, Due Process of Law, Police Power and the Supreme Court, 40 HaRv. L. REv. 943 (I927).

${ }^{00}$ Section 9 r.021 I (f) (1952). 
publication of his plans by building the structure they describe. The answer must be in the negative. It is only by repeated uses of the same set of plans (or modifications thereof) that the architect commences to profit from his intellectual production.

But business intentions aside-is it legally sound to suppose that a completed structure is a publication of its plans? It is submitted that it is not. For a work to be published it must be reproduced, that is, there must be an issuance of copies to the general public. ${ }^{67}$ A completed structure is no more a copy ${ }^{68}$ of its underlying plans than a phonograph record is a copy of its underlying musical notations. An architectural plan is a technical writing. It is capable of being copied only by similar technical writings, that is, by other plans, etc. A structure is the result of plans, not a copy of them. ${ }^{69}$ It follows that building a structure and opening it to public gaze cannot be a publication of its plans. ${ }^{70}$

${ }^{87}$ The United States copyright law, I7 U. S. C. (Supp. 1952), does not define the term publication. (It does define "date of publication" in 17 U. S. C. \$26). The concept that publication requires an issuance of copies of the work to the public is found in the United Kingdom's Copyright Act, rgri, I \& 2 GEO. 5, c. 46, $\$$ I(3). The provision of the English act is modeled after Article 4(4) of the Berne Convention, as revised at Rome, June 2, r928.

A publication presupposes the preservation, in tangible form, of the work concerned so that it is capable of being made available to others. It is for this reason that the performance of a play is not a publication of the play. This viewpoint, which the writer shares with others, is reinforced by an examination of Article VI of the Universal Copyright Convention:

" 'Publication,' as used in this Convention, means the reproduction in tangible form and

the general distribution to the public of copies of a work from which it can be read or otherwise visually perceived."

[The Universal Copyright Convention was drafted at a UNESCO copyright conference held from August 18 to September 6, 1952 in Geneva, Switzerland. The United States was a signatory of the Convention. The State Department has expressed the desire that the Senate ratify the Convention. See Secretary of State Dulles' letter accompanying President Eisenhower's Executive M, issued June 10, 1953, sent to the Senate].

${ }^{\text {as }}$ The copyright definition of the term "copy" bears this point out:

"A copy is that which comes so near to the original as to give to every person secing it the idea created by the original."

Bailey, J., in West v. Francis, 5 B. \& Ald. 743 (1822), cited with approval in White-Smith Music Pub. Co. v. Apollo Co., 209 U. S. I (Ig07).

${ }^{60} \mathrm{~A}$ two or three dimensional model or design for a work of art may be copied by a completed structure based on the model or design. One seeing the completed structure will be seeing a larger representation of the underlying model or design. See Jones Bros. Co. v. Underkoffler, 16 F. Supp. 729 (M. D. Pa. 1936). But this is not the case where the information embodied in a plan is turned into a structure.

It might be noted that Section I3 of the statutory copyright law (17 U. S. C. (Supp. 1952)) requires the proprietor of published works, including architectural technical writings, to deposit "two complete copies of the best edition thereof then published." The Copyright Office has yet to announce that it has either required or received two completed structures as copies of published plans, drawings, and designs!

${ }^{70}$ The correct rule, it is submitted, was enunciated by Vann, J., in Tabor v. Hoffman, II8 N. Y. 30, 3I, 23 N. E. 12, 13 (I889) a case concerning a breach of trust. A repairman was entrusted with a set of construction patterns to aid him in repairing a pump. The repairman made a copy of these patterns for the defendant. The court held:

"... the patterns were a secret device that was not disclosed by the publication of the pump... . While the defendant could lawfully copy the pump, because it had been published to the world, he could not lawfully copy the patterns, because they had not been published, but were still, in every sense, the property of the plaintiff, who owned not only the material substance, but also the discovery which they embodied."

The construction of a work of architecture is not a publication thereof in most of the countries of the world. See e.g., the United Kingdom's Copyright Act, I9II, I \& 2 GEo. 5, c. 46, 51(3); Article $4(4)$ of the Berne Convention, as revised at Rome, June 2, I928. "For the same reason the building will not be a publication of the plans." Copinger on Copyright 213, note (i) . 
For the reasons set forth above, the writer concludes that neither the filing of plans in a governmental office, nor the erection of the structure described in such plans constitutes a general publication of the plans.

Nevertheless, the cases of Wright $v$. Eisle, ${ }^{71}$ Gendell v. Orr, ${ }^{72}$ and Kurfiss $v$. Cowherd, ${ }^{73}$ until distinguished or reversed, represent the only known American case law on the subject. Counsel may avoid the disastrous commercial consequences of those decisions by advising the architect to affix the appropriate statutory notice of copyright in the proper place on each plan, drawing or design before it is filed for building permit purposes. ${ }^{74}$ Should other courts hold that the above decisions truly represent the law, the acts of filing or construction will become general publications ending the period of common law copyright. However, since the "published" work will have already had affixed to it the required notice of copyright, the creator of the architectural plan, drawing or design will immediately be eligible to register a claim to statutory copyright. This point will be developed in the Statutory Copyright section which follows. ${ }^{75}$

\section{Statutory Copyright Protection}

An architectural creation is capable of protection at three stages: (a) as a two dimensional technical writing, that is, as a plan, drawing or design; (b) as a two dimensional artistic representation of the projected structure-or as a three dimensional model of said structure; and (c) as a completed structure.

All three stages are protected in most of the countries of the world, including the United Kingdom. ${ }^{76}$ Unhappily for the American architect, such is not the case in the United States. Architectural plans, drawings, and designs have been the subject of statutory protection in this country only since the passage of the Copyright Act of $1909 .{ }^{77}$ It is not yet clear, to what extent, if any, this statute protects the completed structure itself. This uncertainty stems from the language of the act. In addition to the basic right "to print, reprint, publish, copy and vend the copyrighted work," 78 the statute grants a collateral right "to complete, execute and finish

7186 App. Div. 356, 83 N. Y. Supp. 887 (2d Dep't r903).

${ }^{73} 13$ Phila. 191 (1879).

${ }^{73} 233$ Mo. App. 397, I2I S. W. 2 d 282 (1938).

${ }^{76}$ The above procedure should also be followed where architectural writings are being filed for financing purposes as well. Indeed, the notice of copyright should be affixed should there be any possibility that the writings will be taken from the drafting rooms for any purposes.

${ }^{75}$ See pages 246-247 infra, and cases and notes there cited. See also Katz, Is Notcie of Copyright Necessary in Works Published Abroad?-A Query and a Quandary, WasH. U. L. Q. 55 (Vol. 1953, No. I).

${ }^{70}$ See the fine discussion of the architectural provisions of the British statutes and the Berne Convention in COPINGER ON COPYRIGHT 209-215.

${ }^{77}$ Act of March 4, 1909, 35 Srat. 1075 (1909) et seq., which act, as amended, is currently the law and codified as I7 U. S. C. (Supp. 1952). Registration of the two-dimensional technical writings of an architect is now possible under $\$ 5(i)$ of this act. This section covers: "Drawings or plastic works of a scientific or technical charater." See Regulations of the Copyright Office in 37 Code Fed. Regs. c. II, \$202.10 (1948). See also Copyright Laws of the UnITED States of America (Copyright Office 1952).

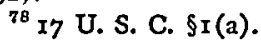


it [the copyrighted work] if it be a model or design for a work of art."70 However, there is no express provision in the current law, as there is in the English copyright act, which affords copyright protection to an architectural work such as a building or other stucture. ${ }^{80}$

The creator of a copyrighted model or design for a work of art has the exclusive right to execute and complete the contemplated structure or object. Architecture is one of the arts. The Copyright Office has long accepted models or designs of architectural works such as dwelling places, mausoleums, and other structures for registration as models or designs for works of art. ${ }^{81}$ It would appear that an architect may obtain the exclusive right to build the structure he has designed if he registers a claim to copyright in his model or design-as opposed to merely copyrighting his plans. ${ }^{82}$ Indeed, a leading modern text writer has declared: ${ }^{83}$

... no good reason seems to exist, under this section $[\mathrm{I}(\mathrm{b})]$, why adequate protection may not be obtained by architects if they copyright their models or designs.

The right under Section $\mathrm{I}(\mathrm{b})$ is apparently limited to completing the contemplated work only. Thus, if an architect designed a civic monument and copyrighted his design or model, he had the exclusive right "to complete, execute and finish it." But having once constructed the monument, others could now freely copy it-provided they did not thereby copy those technical writings which the architect may have also copyrighted.

To the architect who designs "one of a kind" structures, such as bridges, skyscrapers, and luxurious custom-built houses, the protection afforded by Section $\mathrm{I}$ (b) is adequate. This would not be the case where the architect was engaged in designing private dwellings for small rental units. Here repetition, with limited variations, of the basic model or design is the means whereby the architect collects the bulk of his fees. Section $I(b)$, under the above interpretation, would protect him only in the completion of the first structure. Thereafter, such protection as was available would have to come from the copyrighting of his technical writings: his plans, drawings, and designs.

Section I(a), which grants to the copyright proprietor the exclusive right "to print, reprint, publish, copy and vend the copyrighted work," extends its protection to architectural plans, drawings, and designs. ${ }^{84}$ No other section of the copyright law is applicable to these technical writings. The section is designed solely to prevent

${ }^{70}{ }_{17}$ U. S. C. $\$ \mathrm{r}$ (b) (Supp. 1952). These models or designs are registered under $\$ 5(\mathrm{~g})$ of the current law. See Regulations of the Copyright Office in 37 Code Fed. Regs. c. II, \$202.8 (1948).

The Act of July 8, 1870 , \$86, was apparently the first federal copyright act to protect "models or de. signs intended to be perfected as works of the fine arts." The exclusive right was given to execute and finish them.

${ }^{80}$ Copyright Act, I9II, x \& 2 GEo. 5, c. 46, $\S 1,35$ (I). Meikle v. Maufe, 85 S. J. 378 (194I).

${ }^{81}$ In a reply to a letter by the writer, Mr. Arthur Fisher, Register of Copyrights, indicated his Office has made many registrations of such models and designs. He, of course, rendered no opinion as to the judicial interpretation of the scope of such copyrights.

${ }^{82}$ See Jones Bros. Co. v. Underkoffler, t6 F. Supp. 729 (M. D. Pa. 1936) (memorial).

"8s Weil, american Copyrigert Law 83, 84 (xgry).

84 See note 34 supra. 
the protected work from being "copied," that is, there may be no unauthorized printing, reprinting, publishing, copying or vending of the work. Any use of the intellectual production which does not constitute a copying is not an infringement of Section $I(a)$.

The creators of such intellectual productions as books, periodicals and maps are adequately protected under Section I(a). The moment a book, periodical or map is published, it can be fully exploited, culturally as well as commercially. These works need merely be sold to be of value to their creators, and to be read, to be of value to the user. Nothing more must be done. The prevention of copying gives the authors of these works all the protection they need.

However, there are many intellectual productions which are neither economically nor intellectually complete when rendered solely as published copies. Music is not fully exploited merely by the printing of notes on paper. It springs into life only when these notes are played. A lecture may be enjoyed when published as a book; nevertheless, to be fully exploited, it is necessary that it be delivered before an audience. Dramatic works (and these include motion pictures) may be read and disseminated as plays and scripts. However, they are of limited value unless they are performed. A representation of a contemplated piece of sculpture will not impart the true nature of the work until the representation is executed. By the same token, an architect's plans, drawings, and designs are of little practical value until their information is turned into a structure. Clearly, something additional must be done with certain works to make them more valuable to the creator and the public.

Section I(a) is concerned solely with the "copy-right." It is incapable of adequately protecting works which are primarily intended to be played, delivered, performed or executed. As a result, the creators of all these classes of works, with one notable exception, are given certain additional exclusive rights. Thus, in addition to his copy-right, the composer of copyrighted music enjoys the exclusive right to arrange and adapt his music, ${ }^{85}$ and to control its public performance for profit ${ }^{80}$ and its recordation or mechanical reproduction. ${ }^{87}$

Architectural plans, drawings, and designs are no more an end in themselves than is a piece of sheet music. They are primarily intended to be executed, to be turned into structures. The publishing and vending of copies is purely incidental. Nevertheless, under the current copyright law, the architect does not have the exclusive right to build the structures embodied in his technical writings. $\mathrm{He}$ is limited to such protection as is afforded him by his "copy-right" in these writings. Accordingly, we turn to a discussion of the "copy-right," what it protects and the means whereby it is infringed.

The copyright protection of a work under Section $x$ (a) does not extend to the words or ideas used. ${ }^{88}$ It embraces solely the arrangement of the words ${ }^{8 \theta}$ or the ex-

${ }^{85} 17$ U. S. C. $\S \mathrm{I}(\mathrm{b})$ (Supp. I952). $\quad{ }^{80} \mathrm{Id}$. §I(c). $\quad{ }^{87}$ Ibid.

${ }^{88}$ This point is too well established to require references to authorities. However, the reader is referred to the careful statement of Judge Erle in Jefferys v. Boosey, 4 H. L. Cas. 815, 867, Io Eng. Rep. $68 \mathrm{r}, 702$ ( 1854 ) which is quoted on page 232 supra.

80 "A copyright extends only to the arrangement of the words. A copyright does not give a 
pression of the ideas. ${ }^{90}$ Copyright in a work does not prevent others from using the information it contains, ${ }^{91}$ from employing the systems it explains ${ }^{22}$ or from constructing the devices it describes. ${ }^{03}$

To be protected, a work need merely be original, that is, the product of one's own labors. Novelty is no factor. These points have been noted previously. ${ }^{04}$ it is thus conceivable that the material to which protection is extended may parallel or even be identical with matter long in the public domain. As Judge Learned Hand has remarked: $:^{95}$

[the work in question] ... must be deemed to be original, if by original one means that it was the spontaneous, unsuggested result of the author's imagination. . . . this . . . squarely raises the question whether it be a defense to a copyright that the precise work has independently appeared before it and is in the public domain.

Section 7 [now Section 8] ... provides that "no copyright shall subsist in the original text of any work which is in the public domain." This is not new law, and means no more than that by taking such a text you may not get a copyright upon it. ... It has no application whatever to a work which is of original composition, because such a work is not the "original" text of any work in the public domain, but a second and equally "original" text of a work never published before its copyright.

The copyright law, unlike the patent law, has no doctrine of anticipation. ${ }^{08}$ Originality is the sole test of the validity of a copyright. ${ }^{97}$ But the whole work need not be original. As Drone has pointed out: ${ }^{98}$

monopoly in any incident in a play. Other authors have a right to exploit the facts, expericnces, field of thought, and general ideas, provided they do not substantially copy a concrete form in which the circumstances and ideas have been developed, arranged, and put into shape." (Italics supplied.) Manton, D. J., in Eichel v. Marcin, 24I Fed. 404, 408, 409 (S. D. N. Y. 19I7); Holmes v. Hurst, I74 U. S. 82 (I899).

90 '. . . only in the 'expression' of a copyrighted work does any monopoly inhere; the 'theme, the 'plot,' the 'ideas' may always be freely borrowed." Per curiam [L. Hand, A. N. Hand, Clark], Dellar v. Samuel Goldwyn, Inc., r5o F. 2d 6r2 (2d Cir. 1945).

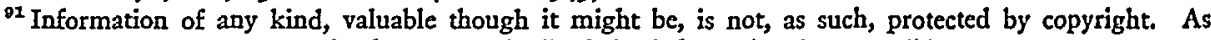
indicated in note 90, supra, only the "expression" of the information is protectible.

As Judge Learned Hand has pointed out: ". . . it has never been very satisfactorily established, and probably never can be, at what point a plagiarism ceases to copy the expression of an author's ideas and steals only the ideas themselves." Fitch v. Young, 230 Fed. 743, 745-746 (S. D. N. Y. I9I6).

${ }^{82}$ Baker v. Selden, ror U. S. 99 (1879). See also, the "Bank Night" cases which concerned the attempt to protect motion picture advertising and promotion systems, Affiliated Enterprises, Inc. v. Gruber, 86 F. 2d 958 (Ist Cir. I936); Affiliated Enterprises, Inc. v. Gantz, 86 F. 2d 596 (roth Cir. 1936).

${ }^{93}$ Muller v. Triborough Bridge Authority, 43 F. Supp. 298 (S. D. N. Y. 1942). Note that this decision states defendant could use plaintiff's copyrighted drawing in designing and constructing a bridge approach. However, the discussion is silent as to whether the drawing could be copied in the process. The decision should be read with this point in mind.

Of course, where the copyright grants an exclusive execution right, as with models and designs for works of art, the right to construct the described device is barred by the copyright. See p. 238 supra, and notes and cases there cited.

o" See pages 231-232 stipra, and cases and notes there cited.

${ }^{25}$ Fisher v. Dillingham, 298 Fed. 145, I49 (S. D. N. Y. 1924).

oo "Two map makers, collecting at first hand, would naturally make the same map and cach would equally be entitled to copyright. In this respect copyright law differs from patent law, where a first use bars others from the same field." BOwker, COPYruchT-ITs History aNd ITs Law 255 (I912).

${ }^{97}$ Fisher v. Dillingham, 298 Fed. 145, 149-152 (S. D. N. Y. 1924). See Yankwich, Originality in the Law of Intellectual Property, II F. R. D. 457 (195I).

${ }^{98}$ Drone on Copyright 199-200. 
In many cases the author has created the substance as well as the form of the composition for which he claims copyright; and, though the sentiments and thoughts may not all be original, neither the whole nor a material integral part of the composition can be said to have previously existed. Popularly speaking, the work is wholly new and original. But the law does not require that a person, to be entitled to copyright, shall be the sole creator of the work for which protection is claimed. Labor bestowed by one person on the production of another, if no rights are thereby invaded, will often constitute a valid claim for copyright . . . Anyone, by making material changes, additions, corrections, improvements, notes, comments, etc., in the unprotected work of another, may create a valid claim for copyright in a new and revised edition.

Too often courts severely limit the copyright protection of a work by "dissecting" it. ${ }^{99}$ First they subtract from the work (assuming it to be a literary work) such things as "old plot," "stock characters," "basic human emotions"-the common-place materials from which all stories are fashioned. The little that remains is then held to be protectible. ${ }^{100}$ It is submitted that this practice is improper. An intellectual production must be viewed en masse to determine its protectibility. Obviously, every individual word in a literary work is in the public domain. A complete exercise of literary dissection would thus destroy all claims to copyright protection. It must be emphasized that copyright protection does not extend to words but only to their arrangement, nor to ideas or sentiments but solely to their expression, development or treatment. It is the impact the creator's artistic personality has on common-place material which sets his work apart-which makes it peculiarly his own. It is this quality of "ownership" which the copyright protects. ${ }^{101}$

${ }^{90}$ Dissection, in the sense as employed by the writer in the text above, is to be distinguished from its sometimes proper use to determine whether one work infringes another. See Arnstein v. Porter, 154 F.2d 464 (2d Cir. I946). See also Nimmer, Inroads on Copyright Protection, 64 HARv. L. Rev. II25 (I95I), Fourth Copyricht LAW SxMposium 2 (ASCAP 1952). See also note x05, infra.

${ }^{100}$ The pitiful results of this dissection technique may be noted in the series of recent California Supreme Court decisions: Weitzenkorn v. Lesser, 97 U. S. P. Q. 545, 40 A. C. 8r3, 256 P. 2 d 947 (Sup. Ct. Calif. April 29, I953); Kurlan v. Columbia Broadcasting System Inc., 97 U. S. P. Q. 556, 256 P. 2d 962, 40 A. C. 833 (Sup. Ct. Calif. April 29, I953); Burtis v. Universal Pictures Co., Inc., 97 U. S. P. Q. 567,40 A. C. 857,256 P. 2 d 933 (Sup. Ct. Calif. April 29, r953). See note rox infra.

101 "Others are free to copy the original. They are not free to copy the copy. . . . The copy is the personal reaction of an individual upon nature. Personality always contains something unique. It expresses its singularity even in handwriting, and a very modest grade of art has in it something irreducible, which is one man's alone. That something he may copyright unless there is a restriction in the words of the act." Mr. Justice Holmes in Bleistein v. Donaldson Lithographing Co., I88 U. S. 239, 249-250 (I903). (Italics supplied.)

A recent review of a western novel, which is here set forth, is directly in point:

"This department is always delighted to receive anything by Frank O'Rourke. There's really nothing new in the plot of his latest, "Gun Hand" (Ballantine, \$2 cloth, 35c paper). John McCabe isn't the first hero of Western fiction to prove himself strong when others are weak, efficient when others stumble. Other fictional towns, like Niobebe, have been under the thumb of a well-organized outlaw gang which loots the wagon trains, kills teamsters and runs crooked games as a sideline. Other men, like $\mathrm{McCabe}$, have been forced to buckle on their guns when matters came to a showdown, and countless other men have found soft arms about their necks on the final page. The difference between "Gun Hand" and the ran-of-the-mill Western is O'Rourke, who again shows the same skill in narration, in character portrayal and in sustained action that earned 'Concannon' and 'The Gun' this column's highest praise. A triple A, therefore, to O'Rourke and "Gun Hand." It's a pippin!" (Italies supplied.) Hoffman Birney, Roundup on the Western Range, N. Y. Times, Nov. 15 , x953, 57 , pt. I, p. 36, col. 3. See also note 46 supra. 
Lines, curves, angles, and squares are some of the "geometric words" used by an architect in his technical writings. These words of his are clearly in the public domain. Every architectural plan, drawing, and design is an amalgam of lines, curves, angles, and squares. Subtracting them from a technical writing would leave the architect without any protectible property. This "syllogism" is neither logically nor legally correct.

It is the arrangement of the lines, curves, angles, and squares which enables the architect to express his artistic personality. Admittedly, he is working with individual materials, each of which has been known since time immemorial. If the architect's arrangements and modes of expression are original, are his alone, are not copied from the work of others or consciously appropriated from arrangements and modes of expression in the public domain, then his technical writings are eligible for copyright protection. His technical writings may be common-place in conception, undistinguished in design, and unimaginative in make-up. His profession and the uninspired public may consider his work "unoriginal," "old hat," "nothing really new." Nevertheless, this architect's writings are copyrightable; “. . . the 'originality' required [by copyright law] refers to the form of expression and not to novelty in the subject matter."102

The technical writings of an architect are infringed when a substantial part of the protectible material has been copied. This is the same rule applicable to all works protected under Section $I(a) .{ }^{103}$ As indicated previously, ${ }^{104}$ the doctrine of "fair-use" permits a limited or non-substantial amount of copying. What, then, is a substantial copying? This is more a question of quality than quantity. The test appears to be: If that portion of a work is taken upon which its commercial or artistic success depends, the taking will be deemed substantial, regardless of the small volume which the misappropriated portion bears to the total mass of the work. $^{105}$ Thus, the copying of a single key musical phrase from a popular song

${ }^{102}$ Frank, C. J., in Chamberlin v. Uris Sales Corp., I50 F. 2d 512, 513 (2d Cir. I945).

103 "The true test of piracy ... is not whether a composition is copied in the same language or the exact words of the original, but whether in substance it is reproduced; not whether the whole, but whether a material part, is taken." DRONE ON COPYrieHT 385.

"Where [architectural] plans are alleged to be infringed by other plans or sketches, the question to be decided is similar to that arising in connection with other artistic works. . . " Copinger on Copyriomr 2I4.

See Ideal Aeroplane \& Supply Co., Inc. v. Brooks, 18 F. Supp. 936 (E. D. N. Y. x937) (prcliminary injunction granted), 34 U. S. P. Q. 370 (E. D. N. Y. 1937) (infringement found at trial on merits) (the technical writing here concerned was a diagrammatic instruction sheet showing method of assembling a ship model).

${ }^{104}$ See pages 228-229 supra, and cases and notes there cited.

${ }^{105}$ Extracts from three cases set forth below clearly enunciate the rule:

"In order to constitute an infringement of the copyright of a book it is not nccessary that the whole or even a large portion of the book shall have been copied. It is sufficient if a material and substantial part shall have been copied, even though it be but a small part of the whole." Maris, J., in Henry Holt \& Co., Inc. v. Liggett \& Mycrs Tobacco Co., 23 F. Supp. 302, 303 (E. D. Pa. 1938).

"A part, however small, of a work which is appropriated is material where the result of the appropriation is the suggestion or impression of similarity or identity." Lehman, J., in Fendler v. Morosco, 253 N. Y. 281, 292, I7I N. E. 56, 60 (1930). 
was held to be a substantial taking. ${ }^{108}$

For a plaintiff to prevail in a copyright infringement suit, he must establish that the defendant copied from his work and that this copying was not a fair use and was, therefore, an infringement. ${ }^{107}$ However, as Judge Learned Hand has indicated: $:^{108}$

One may infringe a patent by the innocent reproduction of the machine patented, but the law imposes no prohibition upon those who, without copying, independently arrive at the precise combination of words or notes which have been copyrighted.

Where the subject matter of intellectual productions is by nature similar, as would be the case with ranch-house-style residences containing a set number of rooms, the resulting plans of two different architects could contain close resemblances. The legal question is whether these resemblances have naturally resulted from a general use of common sources and materials open to both architects, or whether one architect used the work of the other as a model, copying from it rather than drawing from the common sources. ${ }^{109}$

In every case concerning infringement by copying, the courts look for some evidence of access, for some indication that the defendant had contact with, or knowledge or awareness of, the plaintiff's work. But access, after all, is only a piece of circumstantial evidence. Striking similarities and repetition of common errors are but two means of satisfying the proof of lack of access. ${ }^{110}$

The most obvious means of infringing a copyrighted architectural plan, drawing, and design is to copy directly from the original work itself. This may be accomplished by a tracing, photograph or other mode of direct reproduction.

Infringement by copying, however, may also be done indirectly. ${ }^{111}$ It may be

". . . the defendant has not appropriated the entire copyrighted work, but he has materially diminished the value of complainant's work and appropriated its labors to an injurious extent. This constitutes infringement." Hollister, D. J., in Meccano v. Wagner, 234 Fed. 912, 922 (S. D. Ohio 1916).

Whether the copying is of such nature as to be an infringement is a question of fact to be determined by laymen and not by experts. Gross v. Seligman, 212 Fed. 930, 93I-32 (2d Cir. I9I4); Arnstein v. Porter, I54 F. 2d 464, 469 (2d Cir. 1946).

${ }^{100}$ Boosey v. Empire Music Co., Inc., 224 Fed. 646, 647 (S. D. N. Y. 1915) (phrase: "I hear you calling me" with accompanying music almost identical with that of plaintiff's).

${ }^{107}$ Arnstein v. Porter, I54 F. 2d 464,468 (2d Cir. 1946).

${ }^{108}$ Fisher v. Dillingham, 298 Fed. 145, 147 (S. D. N. Y. 1924).

${ }^{100}$ Emerson v. Davies, 3 Story $768,793,8$ Fed. Cas. No. 4.436 , at 626 (C. C. D. Mass. 1845 ).

110 "Substantial identity, or a striking resemblance, between the work complained of and that for which protection is claimed, creates a presumption of unlawful copying, which must be overcome by the defendant." Drone on Copyrigrt 400; Lawrence v. Dana, I5 Fed. Cas. No. 8, 136 , 26, 6o (C. C. D. Mass. 1869 ).

"Errors in typography and in matter appearing in appellant's book first occurred in appellee's. There were enough errors to repel any theory of accidental coincidence and to warrant a finding of intentional trespass upon appellee's property. Such a situation justified a further finding that appellant's copying was not confined to copying appellee's mistakes." Baker, C. J., in Investment Service Co. v. Fitch Publishing Co., 29I Fed. roro (7th Cir. 1923).

112 "Infringement may be by indirect as well as by direct copying. In the case of Cate v. Devon in 1889, in the Chancery Court, the defense that the copying was not from the original copyright work but from a newspaper reprint, was rejected." Bowker, Copyright-Its History aNd Its Law 254 (19I2).

See also Gross v. Seligman, 212 Fed. 930 (2d Cir. r914) (The decision in this case was rendered 
done from memory. ${ }^{112}$ The infringer may once have seen the plans, and later commits their features to paper. The moment he does so, he has made an infringing copy of them. ${ }^{113}$ He will also infringe, although he may never have seen the original plans, if he makes a copy of them pursuant to the instructions of one who has. The same result obtains where he copies a plan from one who has copied the original. ${ }^{114}$ Clearly, infringement by copying may occur unintentionally. This is so since the copyright law does not require an intent to copy, other than where a criminal action for willful infringement is being brought. ${ }^{115}$ Nevertheless, a showing of the intention to copy or "steal" is valuable in determining whether basic similarities constitute an infringement or are merely coincidental. ${ }^{116}$

In the absence of proof of direct copying of architectural plans, drawings or designs, it is necessary to prove copying by other means. Here the analogy to the proving of infringement of copyrighted music is particularly apt. One infringes a music copyright by copying down the music he hears being performed-whether the performance is by a "live" orchestra or by a phonograph record. ${ }^{117}$ Neither the interpretive rendition of the orchestra, nor the phonograph record itself, is protected under the copyright law. ${ }^{118}$ If there has been a substantial copying of the

by Judge Lacombe. The writer considers it one of the best reasoned copyright cases he has ever read).

${ }_{112}$ Freudenthal v. Hebrew Publishing Co., 44 F. Supp. 754 (S. D. N. Y. 1942).

${ }^{113}$ The wrong lies in making an unauthorized copy of a work in which the "right to copy" is vested in another. This elementary concept is often overlooked. It was duly noted, however, in Forcign \& Domestic Music Corp. v. Licht, I96 F. 2d 627 (2d Cir. r952).

116 The fact that the one making the copy may not realize he is committing a wrong in following the advice of another is no bar to his legal liability. To hold otherwise would prevent the copyright proprietor from effectively protecting his property. See note 115, infra.

"It has been held that one who copies from a plagiarist is himself necessarily a plagiarist, however, innocent he may be (American Press Assoc. v. Daily Story Publishing Co., 120 Fed. Rep. 766 (C. C. A. 7) ... The wrong is copying; that is, using the author's work as a source. A copy of a copy does indeed do just that. ..." Per curiam, Barry v. Hughes, I03 F. 2d 427 (2d Cir. I939) (L. Hand, Clark, Patterson).

110 "To constitute piracy, it is not necessary that there shall have been on the part of the wrong-doer an intention to pirate. His motives in taking the whole or a part of the copyrighted work may have been ... commendable... In applying the law, the thing done and its effect, and not the intention with which it is done, are the controlling considerations." Drone on Copyrigrr 401, 402. Sec also Lawrence v. Dana, 15 Fed. Cas. No. 8,136, 26, 60 (C. C. D. Mass. 1869).

The statutory copyright provisions on willful infringement are contained in I7 U. S. C. $\$ \$ 104,1 \times 5$ (Supp. x952).

116 ".. . Where it can be readily shown that there has been material copying, it matters not with what intent the copying was done; but where it is difficult to ascertain the extent of the copying . . . the animus furandi may aid in the solution of the question." Drone ON Copyruarr 402.

Accord: Harold Lloyd Corp. v. Witwer, 65 F. 2d I (9th Cir. 1933); Meccano v. Wagner, 234 Fed. 9 r2 (S. D. Ohio r9r6).

${ }^{117}$ Cf., Fisher v. Dillingham, 298 Fed. I45 (S.D.N.Y. 1924).

See page 239 supra, for those rights, in addition to his "copy-right," which are cnjoyed by the owner of copyrighted music.

${ }^{218} \mathrm{~A}$ phonograph record is not a copy of a musical work since it has been held to be a part of an instrument reproducing sound; as such it is not copyrightable. White-Smith Music Co. v. Apollo Co., 209 U. S. I (1907).

Interpretive renditions are not protected by statutory copyright. Further, any common law rights which a performer might have in his rendition cease upon the release of the recorded performance to the public. R.C.A. Manufacturing Co. v. Whiteman, Ix4 F. 2d 86 (2d Cir. 1940). Contra: Waring v. WDAS Broadcasting Co., 327 Pa. 433, r94 Atl. 63x (1937). 
music, an infringement occurs, notwithstanding that the thing or object from which the music is copied is itself not capable of copyright protection. ${ }^{118}$ The same result follows where architectural writings are concerned.

Perhaps the most usual method of copying architectural plans, drawings, and designs is that where the infringer actually copies from the completed edifice and not directly from the copyrighted technical writings themselves. The structure, it is clear, is not eligible for copyright protection. Nevertheless, if one paces off distances, measures angles, takes photographs, makes sketches and notes, and, from these varied acts, proceeds to put the information thus garnered on to paper in the form of a plan, drawing or design, an infringement by copying has occurred. ${ }^{120}$

By its very nature, no modern structure designed for human use or habitation may be built without reference to the technical writings of an architect. Furthermore, no building permits may be granted unless approved plans, drawings, and designs have been filed in the appropriate governmental offices. Nor can financing be arranged with private or governmental lenders unless these same writings are examined and approved. Where architectural plans, drawings, and designs are found to be infringed, the court will order the destruction of all infringing copies. ${ }^{121}$ A permanent injunction will also issue against further copying of these copyrighted writings. ${ }^{122}$ It will thus be possible effectively to halt the building activities of the infringer. He will have no infringing copies available for building permit or loan purposes, and none for use on the job. The infringer is not denied the right to use the information or ideas expressed in the original technical writings. $\mathrm{He}$ is merely enjoined from copying the copyrighted technical writings, and is made to give up all offending copies.

An architect's rights under statutory copyright are limited. He does not have the exclusive right to execute his technical writings. He most probably has the right to complete, execute, and finish the structure which is based upon his copyrighted model or design. ${ }^{123}$ In all other cases, other persons may build the structures

\footnotetext{
110 This is not an improper extension of the concept of copyright. Copying a recording by making a pressing of it is not a violation of the "copy-right" in the music-although it is certainly an act of unfair competition. (It may, under certain circumstances, be a violation of the "recording right" in the music, see page 239 and notes 86,87 supra.) However, making a copy of the musical notes themselves is a violation of the copyright. See page 244 and notes $1 \times 3$, II4 supra.

${ }^{120}$ The test of infringement is whether the questioned work is "recognizable by an ordinary observer as having been taken from the copyrighted source. Such is an infringement." Manton, C. J., in Fleischer Studios v. Ralph A. Freundlich, 73 F. 2d 276, 278 (2d Cir. 1934).

"Infringement may be through quite a different medium from the original. . ." BowkER, CopyRIGHT-ITS History AND ITs LAW 254 (IgI2). Lawrence v. Dana, I5 Fed. Cas. No. 8, I36, 26, 59-60 (C. C. D. Mass. 1869 ). Thus, disguising the source from which the infringer took his material does not defeat plaintiff's copyright. King Features Syndicate v. Fleischer, 299 Fed. 533, 535 (2d Cir. 1924). The structure itself may be copied provided the plans are not thereby also copied, see note 70 supra, and page 246 infra.

There need be no literal copying for an infringement to occur, ". . . else a plagiarist would escape by immaterial variations." L. Hand, C. J., in Nichols v. Universal Pictures Corp., 45 F. 2d II9, I2I (2d Cir. 1930). See note 103, stipra. For the effect on the charge of copyright infringement of material variations, see page 246 and note 124 infra.

121 I7 U. S. C. \$roI (d) (Supp. I952)

${ }^{122}$ Id. $\$ \operatorname{Ior}(\mathrm{a})$.
}

123 See pages 237-239 supra, and notes thereto. 
he has designed. However, they must build these structures without copying his copyrighted plans, drawings, and designs. This is the sole effective measure of protection available to the architect.

Enforcement of an architect's copy-right creates no threat of monopoly. If persons wish to build from his technical writings, let them buy their copies from him. If they wish to profit from his ideas, techniques, and theories in drafting their own technical writings, let them, provided their resultant writings are so materially altered as to constitute non-infringing "new works."124

For an architect to obtain such protection as is available to him under statutory copyright law, he must carefully comply with its many technical requirements. Thus, he must publish his plans, drawings, and designs with a valid notice of copyright. ${ }^{125}$ To be valid the notice must be in the proper form, ${ }^{126}$ must be applied in the proper place, ${ }^{127}$ and must appear on every authorized reproduction of these writings. ${ }^{128}$ Publication with a valid notice of copyright merely preserves the work's etigibility for copyright. A claim of copyright must still be registered. ${ }^{120}$ Promptly after publication of his work, the claimant must deposit "two complete copies of the best edition thereof" in the Copyright Office in order to "perfect" his copyright. ${ }^{130}$ Until copies are deposited, no suit for infringement can be maintained. ${ }^{131}$

For the convenience of the Copyright Office, Section 5 of the copyright law classifies works for copyright registration purposes. ${ }^{132}$ Architectural plans, drawings, and designs are contained within subdivision (i) ${ }^{133}$ while models and designs for architectural structures fall into subdivision $(\mathrm{g}) .^{134}$ Works within these subdivisions are permitted a number of variations in the form of the copyright notice. ${ }^{185}$ However, the safest notice, and by far the simplest, is cast in this form: Copyright by John Doe.

Although common law copyright concerns itself solely with unpublished works,

124 Under copyright principles the protected matter may not be copied. Making immaterial changes in the arrangement of the protected work or in its mode of expression, will not cloak an infringement. However, one may take the copyrighted work and materially alter it so that a "new work" is evolved. This second work is new in the sense that it is different in arrangement, expression, and treatment from its source. It is not its copy. The new work is itself capable of copyright protection.

". . . even assuming the book to have suggested the Chinese den feature to the writer of the [motion picture] scenario, he has brought about such a material alteration in the constituent parts of the serics of events, and in the sequence of the events in the series, as to escape the charge of plagiarism with respect thereto." Knox, J., in Curwood v. Affiliated Distributors, 283 Fed. 223, 228 (S. D. N. Y. 1922). (Italics supplied.)

${ }_{125}^{20}$ I7 U. S. C. §ro (Supp. x952). 120 Id. \$19.

${ }^{127} I d$. \$20. $\quad{ }^{128}$ Id. \$10. ${ }^{120}$ Id. \$II.

${ }^{130} \mathrm{Id}$. $\$ \$ 13$, I4. For a discussion of this point and of the copyright formalities noted above, see Katz, Is Notice of Copyright Necessary in Works Published Abroad?-A Query and a Quandary, WAst. U. L. Q. 55 (Vol. I953, No. I).

${ }_{131} x_{7}$ U. S. C. $\$$ I3. See Washingtonian Pub. Co. v. Pearson, 306 U. S. 30 (1939).

${ }^{132}$ I7 U. S. C. $\$ 5$ (Supp. 1952). It was within this section that the architect's technical writings are first expressly mentioned in United States copyright law. See page 237 supra, and note 77 thereto. See also the House of Representative's Committee Report on Bill Enacting Copyright Act of I909, set forth in Howell, The Copyright LAw 253, 264 (3d ed. 1952).

${ }^{133}$ Id. $\$ 5$ (i). Drawings or plastic works of a scientific or technical character. See note 77 stlpra.

${ }^{134} I d$. $\$ 5(\mathrm{~g})$. Works of art; models or designs for works of art. See note 35 supra.

${ }^{136} \mathrm{Id}$. \$Ig. These concern means of abbreviating the notice. 
United States statutory copyright protects all published works and certain unpublished works as well-provided these comply with its requirements. This latter class includes works which are not "realizable" or fully exploited unless something additional is done with them. Within this grouping are such intellectual productions as musical and dramatic works, works of art, and the technical writings of the architect. Section 12 of the copyright law describes these unpublished creations as "works not reproduced for sale."136

An architect does not generally intend to sell his technical writings outright as published copies. Instead, he receives royalties for the use of these writings and other fees for his accompanying professional services. Accordingly, these unpublished writings are registerable under the above section of the copyright law. Only one copy of these unpublished writings need be deposited. ${ }^{\mathbf{1 3 7}}$ Unpublished works are not required to bear a notice of copyright. ${ }^{138}$ Nevertheless, since the law is uncertain as to which acts constitute a general publication, it is certainly the wisest course to apply the notice of copyright, as required by published works, in the proper place on each of the architect's technical writings before these writings leave the drafting room.

It should be noted that the term of statutory copyright for both published and unpublished works is twenty-eight years, with a second, or renewal term, for an additional twenty-eight years. ${ }^{139}$

A victorious architect in an infringement action is entitled to receive a number of benefits. This includes, among other things, an injunction, ${ }^{140}$ monetary recovery, ${ }^{141}$ destruction of the infringing material,,$^{142}$ court costs, ${ }^{143}$ and, in some cases, attorney's fees. ${ }^{144}$

A brief discussion of those copyright law provisions concerning the monetary recovery, costs, and attorney's fees is in order.

Section ror(b) of the copyright law contains an unusual provision concerning

${ }^{130} I d$. §Y2. See also pages $224,225,239$, supra, for a discussion of the artistic and commercial nature of these unpublished works.

${ }^{137} I d .5 \$ 12,13,14$.

${ }^{138}$ See id. $\$ \$ 10-14$. See also Howell, op. cit. supra note 132 at 107 , 108 for a discussion of this point.

${ }^{130} \mathrm{Id}$. \$24. The renewal copyright is a new grant of copyright. White-Smith Music Pub. Co. v. Goff, 187 Fed. 247 (Ist Cir. I9II). With certain express exceptions only the author of a work may renew it. If he is dead when a work is eligible for renewal, the statute lists those persons who may then renew. Fox Film Corp. v. Knowles, 26r U. S. 326 (x923). As to the assignment of the renewal right see Fred Fisher Music Co. v. Witmark, 318 U. S. 643 (1943).

Where unpublished works are concerned, the measurement of the 28 years runs from the date the work is deposited for copyright. Marx v. United States, 96 F. 2d 204 (9th Cir. 1938).

${ }^{110}$ I7 U. S. C. \$IOI(a) (Supp. 1952). The writer is here talking of a permanent injunction. If by the time suit is brought the infringement has ceased and there is little chance that it will recur, an injunction might not issue. Compare, Sheldon v. Moredall Realty Corp., 95 F. 2d 48 (2d Cir. 1938), with M. Witmark \& Sons v. Calloway, 22 F. 2d 4I2 (D. Tenn. 1927).

${ }^{112}$ I7 U. S. C. $\$ 101(b)$ (Supp. 1952). See note 145 infra, for text of this section.

${ }^{142}$ Id. $\S \mathrm{ror}(\mathrm{d})$. Under $\$ \mathrm{rox}(\mathrm{c})$ articles alleged to infringe the copyright may also be impounded during the suit.

${ }^{143}$ Id. $\$ \mathrm{II} 6$.

14t lbid. See also page 249 and note 152 infra. 
damages and profits. ${ }^{145}$ This provision declares that upon proof of an infringement the plaintiff shall recover such damages as he has suffered by the infringement and "all the profits" made by the infringer from such infringement. In order to recover the foregoing amounts, the plaintiff must prove profits by proving "sales only." Conversely, the defendant has to prove "every element of cost which he claims."

The law recognizes that the above procedure is complicated. Therefore, it is further stated that "in lieu of actual damages and profits" the court may assess "such damages as .. . shall appear to be just." In assessing such damages, the court, "in its discretion," may allow certain stated amounts. In the case of architectural plans, drawings, and designs, and of models and designs for a work of art (all of which fall within Section 5 of the copyright law), the court may assess $\$$ r.oo for each infringing copy made, sold or found in the defendant's possession. However, where a case falls within the provisions of the "in lieu" clause, no award of damages may be less than $\$ 250.00$ or more than $\$ 5,000.00$.

Some cases will illustrate these points. Where either actual damages or actual profits may be ascertained, the "in lieu" clause will not apply. ${ }^{148}$ Where neither can

${ }^{145}$ The involved nature of the section warrants its reproduction:

"Damages and Profits; Amount; Other Remedies.-To pay to the copyright proprietor such damages as the copyright proprietor may have suffered due to the infringement, as well as all the profits which the infringer shall have made from such infringement, and in proving profits the plaintiff shall be required to prove sales only, and the defendant shall be required to prove every element of cost which he claims, or in lieu of actual damages and profits, such damages as to the court shall appear to be just, and in assessing such damages the court may, in its discretion, allow the amounts as hereinafter stated, but in case of a newspaper reproduction of a copyrighted photograph, such damages shall not exceed the sum of $\$ 200$ nor be less than the sum of $\$ 50$, and in the case of the infringement of an undramatized or nondramatic work by means of motion pictures, where the infringer shall show that he was not aware that he was infringing, and that such infringement could not have been reasonably foreseen, such damages shall not exceed the sum of \$roo; and in the case of an infringement of a copyrighted dramatic or dramaticomusical work by a maker of motion pictures and his agencies for distribution thereof to exhibitors, where such infringer shows that he was not aware that he was infringing a copyrighted work, and that such infringements could not reasonably have been foreseen, the entire sum of such damages recoverable by the copyright proprietor from such infringing maker and his agencies for the distribution to exhibitors of such infringing motion picture shall not exceed the sum of $\$ 5,000$ nor be less than $\$ 250$, and such damages shall in no other case exceed the sum of $\$ 5,000$ nor be less than the sum of $\$ 250$, and shall not be regarded as a penalty. But the foregoing exceptions shall not deprive the copyright proprietor of any other remedy given him under this law, nor shall the limitation as to the amount of recovery apply to infringements occurring after the actual notice to a defendant, either by service of process in a suit or other written notice served upon him.

"First. In the case of a painting, statue, or sculpture, \$ro for evcry infringing copy made or sold by or found in the possession of the infringer or his agents or employecs;

"Second. In the case of any work enumerated in section 5 of this title, except a painting, statue, or sculpture, $\$ 1$ for every infringing copy made or sold by or found in the possession of the infringer or his agents or employees;

"Third. In the case of a lecture, sermon, or address, $\$ 50$ for every infringing delivery;

"Fourth. In the case of a dramatic or dramatico-musical or a choral or orchestral composition, \$roo for the first and $\$ 50$ for every subsequent infringing performance; in the case of other musical compositions \$ro for every infringing performance." (Italics supplied.)

${ }^{140}$ Sheldon v. Metro-Goldwyn Pictures Corp., ro6 F. 2d 45 (2d Cir. 1939) (damages); Davilla v. 
be established, the court may then award statutory damages. ${ }^{147}$ Thus, where there is but one infringing copy made of an architect's technical writings, the court cannot award \$1.00-it must award at least $\$ 250.00 .^{148}$ The $\$ 1.00$ figure is important only where there are two hundred and fifty or more infringing copies. In that event, by awarding merely $\$$ I.0o for each infringing copy, the plaintiff would still receive $\$ 250.00$. However, even here the court could award statutory damages up to $\$ 5,000.00$ to cover all the infringing copies. ${ }^{149}$ The court's discretion, of course, is affected by the equities in the case. It must be noted that the minimum or maximum provisions of Section ror (b) are not applicable should the defendant continue to infringe after he has received "actual notice . . . either by service of process in a suit or other written notice served upon him."150

Under Section II6 of the copyright law, the court will allow full costs and "may award to the prevailing party a reasonable attorney's fee as part of the costs."151 The award of attorney's fees is often substantial in light of the judgments obtained. In a recent case a judgment for $\$ 5,000.00$ was coupled with an attorney's fee of $\$ 2,000.00$. $^{162}$ This is cited to indicate that a potential plaintiff as well as prospective infringer might think twice before incurring the risks of copyright litigation.

This article opened with a series of questions. The writer trusts he has answered them correctly. Architectural plans, drawings, and designs are not sui generis as intellectual productions. The protection granted these technical writings under common law and statutory copyright principles is similar in scope to that accorded the intellectual productions of authors, artists, and composers. This protection is adequate. It is not complete. A fuller measure of relief may be possible by drawing upon other fields of law-upon those of contracts, torts, and unfair competition, to name a few..$^{153}$

Brunswick-Balke Collender, 94 F. $2 \mathrm{~d} 567$ (2d Cir. 1938) (profits). For the measurement of lost profits see Gross v. Van Dyk Gravure Co., 230 Fed. 412, 4I4 (2d Cir. 19r6); Taft v. Smith, Gray \& Co., 76 Misc. 283, 134 N. Y. Supp. IorI (Sup. Ct. 1912) (unpublished work protected under common law copyright).

${ }_{147}$ Douglas v. Cunningham, 294 U. S. 209 (1935); Toksvig v. Bruce Publishing Co., r8I F. 2d 664 (7th Cir. 1950).

${ }^{148}$ Cravens v. Retail Credit Men's Ass'n, 26 F. 2d 833 (M. D. Tenn. 1924).

${ }^{160} \mathrm{Krafft} v$. Cohen, 32 F. Supp. $82 \mathrm{I}$ (E. D. Pa. 1940), rev'd on other grounds, II7 F. 2d 579 ( 3 d Cir. r94r) (also spelled Kraft).

${ }^{150}$ Turner v. Crowley, 252 Fed. 749 (9th Cir. 1918).

10117 U. S. C. §116 (Supp. 1952).

${ }^{252}$ Contemporary Arts v. F. W. Woolworth Co., 93 F. Supp. 739 (D. C. Mass. r950), aff'd, I93 F. 2d I62 (Ist Cir. I95x).

253 The law of copyright does not claim to be the alpha and omega of protection for intellectual productions. Thus, many acts, which are actionable wrongs in other fields of law, escape censure when examined solely under copyright principles. The cases and text writers in the Appendix to this article reveal some of those collateral legal principles upon which further protection may be predicated. 
Appendix

Non-Copyright Principles for the Protection of Architectural Plans, Drawings, and Designs

I

Unfair competition as a result of a "passing or palming off" has long been the object of judicial censure. " $B$, in banking on $A$ 's fine reputation passes off his own ( $B$ 's) work as that of $A$. " This is the classic example. Perhaps the more usual method today is that where " $B$ misappropriates $A$ 's work and passes it off as his own ( $B$ 's)." This concept of passing off was recognized by Justice Holmes in International News Service v. Associated Press, 248 U. S. 215, 247 (19r8). As pointed out by Judge Caffey in Jerome v. Twentieth Century-Fox Film Corp., $5^{8}$ F. Supp. 13, I5 (S. D. N. Y. I944) “. . . misappropriation probably is the key to modern unfair competition theory." The cases set forth below illustrates this premise.

\section{Unjust Enrichment}

I. International News Service v. Associated Press, 248 U. S. 215 (Igr8) (Defendant's misappropriation of plaintiff's labor, skill, and organization in the collection of news held unjust enrichment). See also the well reasoned lower court decisions: Associated Press v. International News Service, 240 Fed. 983 (S. D. N. Y. 19r7); 245 Fed. 244 (2d Cir. Igr7).

2. Metropolitan Opera Ass'n v. Wagner-Nichols Recorder Corp., ror N. Y. S. 2d 483 (1950), aff'd, I07 N. Y. S. 2 d 795 (Ist Dep't 1951) (recording radio broadcast of opera performance).

3. Fonotipia, Ltd. v. Bradley, I7I Fed. 95I (C. C. E. D. N. Y. I909) (copying of phonograph records).

4. Victor Talking Machine Co. v. Armstrong, I32 Fed. 7II (C. C. S. D. N. Y. 1904) (copying of process in manufacturing of records).

5. Meccano v. Wagner, 234 Fed. 912 (S. D. Ohio rgr6), rev'd in part, 246 Fed. 653 (6th Cir. Igr8) (improper appropriation of business methods and system).

6. That the wrong where non-copyrightable material is appropriated is the taking of the plaintiff's labor, skill, and organization is clearly noted when Hebrew Publishing Co. v. Scharfstein, 288 N. Y. 374, 43 N. E. 2 d 449 (I942) is compared with Dutton v. Cupples \& Leon, Ir7 App. Div. I72, I02 N. Y. S. 309 (Ist Dep't I907) (copying of book).

\section{II}

Protection is also available where intellectual productions are obtained by breach of contract, breach of trust or other tortious conduct of the defendant. Here the law moves to punish the wrongful act of the defendant rather than consciously to protect the "property" of the plaintiff. "... an injunction may issue even though the copied features are in the public domain and the copying would be permissible were it not for the breach of trust or of contract or the fraud. I NIMs, THE LAw of UNfair Competition and Trade Marks 385 (4th ed. I947). 
Breach of Contract

\section{(express, implied in fact, implied in law)}

I. Board of Trade v. Christie Grain and Stock Co., I98 U. S. 236 (I904) (breach of contract not to make certain information public).

2. High v. Trade Union Courier Pub. Corp., 69 N. Y. S. $2 d$ 526, aff'd., 89 N. Y. S. 2d 527 (r949); Cole v. Lord, Inc., 262 App. Div. II6, 28 N. Y. S. $2 d 404$ (Ist Dep't r94r) (disclosure of ideas protected by contract).

3. Nimmer, The Law of Ideas, 27 So. CALIF. L. REv. Irg (I954).

\section{Breach of Trust}

I. Du Pont de Nemours Powder Co. v. Masland, 244 U. S. I00 (I9I7) ("The property may be denied but the confidence cannot be," Justice Holmes, id. at ro2).

2. Tabor v. Hoffman, II8 N. Y. 30, 23 N. E. I2 (I889) (pump patterns entrusted to repairman).

3. Margolis v. National Bellas Hess Co., I39 Misc. 738, 249 N. Y. S. 175 (Sup. Ct. I93I), aff'd, 235 App. Div. 839, 257 N. Y. S. 912 (Ist Dep't I932) (copying of design submitted on approval; see particularly the listing by Shientag, J., of grounds for protection on page $74 \mathrm{I}$ of the trial report).

4. Booth v. Stutz Motor Car Co., 56 F. 2d 962 (7th Cir. 1932) (drawings and blueprints submitted in confidence to manufacturer).

5. "... the right to restrain the publication of a work upon the ground that to do so would be a breach of trust or confidence is, it is submitted, a larger right than the proprietary [statutory] right of copyright. There can be no copyright in ideas or information, and it is no infringement of copyright to adopt the ideas of another or to publish information received from another, provided there is no copying of the language in which these ideas have, or that information has, been previously embodied; but if the ideas or information have been acquired under such circumstances that it would be a breach of faith to publish them, the courts will grant an injunction against any person who does so" (italics supplied). CopInger on CopYRIGHT 38-39.

\section{Surreptitious Appropriation}

The cases which follow illustrate the point that the tortious or inequitable conduct of the defendant in taking non-protectible articles deprives him of the right to use these articles even though they be free to all others.

I. Montegut v. Hickson, Inc. I78 App. Div. 94, I64 N. Y. S. 858 (Ist Dep't I9I7) (dress designs).

2. Shellmar Products Co. v. Allen-Qualley Co., 87 F. 2d ro4 (7th Cir. I937) (wrap for candy bars).

\section{III}

A work not otherwise protectible under the copyright or patent laws will be protected against misappropriation of its non-functional features. Cheney Bros. v. Doris Silk Corp., 35 F. 2d 279 (2d Cir. I929), cert. denied, 28I U. S. 728 (r930). 


\section{Functional and Non-Functional Features Distinguished}

I. Functional features are those essential to construction of the item concerned so that it functions successfully and may be manufactured at a reduced cost. See 3 Calimann, The Law of Unfair Competttion and Trade Marks i253 (2d ed. 1950); i Nims, The Law of Unfair Competition and Trade Marks 370 (4th ed. 1947); Kellogg Co. v. National Biscuit Co., 305 U. S. III (1938).

2. Non-functional features "are either ornamental, or distinctive, or both. . .." (Italics supplied.) 3 Callmann 1259. See also I Nims 370.

\section{Nature of Protection}

\section{A. Functional Features:}

r. The functional features of an article not otherwise protected may be copied. 3 Callmann i254; i Nims 370.

2. But this copying must not confuse the public with regard to the origin of the goods. 3 CallmanN I254; I Nims 370.

3. "Such confusion does not necessarily entitle the original user to enjoin the use of such features, but it does give him the right to demand that a competitor adequately distinguish his product." I NIMs $37 x$. If this is impossible, ". . . the confusion must be accepted...." 3 Callmann 125\%. See also Flagg Mfg. Co. v. Holway, I78 Mass. 83, 59 N. E. 667 (xgor); Shredded Wheat Co. v. Humphrey Cornell Co., 250 Fed. 960 (2d Cir. Igr8).

B. Non-Functional Features:

I. The copying of non-functional features of an article not otherwise protected may constitute unfair competition. 3 CaIIMANN I254; I Nims 370, 378.

2. Some courts grant recovery (a) where it is shown non-functional features have been copied on the premise the public will be deceived. The majority of courts (b) will protect only those non-functional features which have acquired secondary meaning.

The leading case illustrating point (a) above, is Rushmore v. Manhattan Screw \& Stamping Works, 163 Fed. 939 (2d Cir. Ig08).

The leading case illustrating point (b) above, is Crescent Tool Co. v. Kilborn \& Bishop Co., 247 Fed. 299 (2d Cir. 1917).

California follows the rule set forth in the Rushmore case. Grant v. California Bench Co., 76 Cal. App. 2d .706, r73 P. 2d 8i7 (r946).

IV

\section{Protection Under the Lanham Act}

The Lanham Trade Mark Act was enacted into law on July 5, r946. 15 U. S. C. $\$ \$$ I05I-Ix27, 60 STat. 427. One of its ostensible purposes was to counteract the effects of Erie R. R. v. Tompkins, 304 U. S. 64 (1938) which declared that there was no federal common law. Sections $I I 26(b)(h)(i)$ and $I I 27$ make acts of unfair competition affecting interstate and foreign commerce matters which come exclusive- 
ly within the orbit of the federal courts. It is apparently the intent of the act that citizens and residents of the United States shall now have the same protection against questionable business activities as the United States grants the nationals of those countries adhering to (a) the Paris Convention of March 20, 1883 for the Protection of Industrial Property, as amended at London, June 2, 1934, and (b) the PanAmerican Convention of February 20, 1929 (Washington, D. C.).

Article so bis of the London Convention and Articles 20 and 2I of the PanAmerican Convention offer a broader interpretation of acts of unfair competition than that generally followed in the United States. Whether this broader interpretation is applicable to disputes solely between citizens or residents of the United States is unfortunately not yet resolved. The cases and text writers set forth below are among those who maintain that the broader basis is applicable.

I. Stauffer v. Exley, I84 F. 2 d 962 ( 9 th Cir. I950).

2. Pagliero v. Wallace China Co., Ig8 F. 2d 339 (9th Cir. r952).

3. Steele v. Bulova Watch Co., 344 U. S. 280 (1952).

4. 4 Callmann, The Law of Unfair Competition and Trade Marks 2208 (2d ed. 1950 ).

5. Daphne Robert, Commentary on the Lanham Trade-Mark Act, at pp. 265, 284-286 of I5 U. S. C. A. (following \$1024).

\section{$\mathrm{V}$ \\ Patent Law Protection}

See 35 U. S. C. \$I et seq., 66 STaT. 792 (Supp. I952). See particularly sections IOr and ro2 which set forth the basis for patentability, and section I7I which concerns design patents.

\section{VI}

Protection of Ideas

See Nimmer, The Law of Ideas, 27 So. CaLif. L. Rev. Ir9 (1954).

\section{VII}

\section{Protection Under the Moral Right Doctrine}

See Katz, The Doctrine of Moral Right and American Copyright Law-A Proposal, 24 So. Calif. L. Rev. 375 (195I), Fourth Copyright Law Symposium 78 (ASCAP I952); Roeder, The Doctrine of Moral Right: A Study in the Law of Artists, Authors, and Creators, 53 HaRv. L. Rev. 554 (I940); Granz v. Harris, rg8 F. 2d 585, 590, 59r (2d Cir. I952). 